\title{
Hahella antarctica sp. nov., isolated from Antarctic seawater
}

Correspondence

Jang-Cheon Cho

chojc@inha.ac.kr
Kiyoung Lee, ${ }^{1}$ Hong Kum Lee ${ }^{2}$ and Jang-Cheon Cho ${ }^{1}$

\author{
${ }^{1}$ Division of Biology and Ocean Sciences, Inha University, Yonghyun-Dong, Incheon 402-751, \\ Republic of Korea \\ ${ }^{2}$ Polar BioCenter, Korea Polar Research Institute, KOPRI, Songdo Techno Park, Incheon 406-840, \\ Republic of Korea
}

\begin{abstract}
A Gram-negative, psychrotolerant, chemoheterotrophic, aerobic, cream-coloured bacterium, designated IMCC $3113^{\top}$, was isolated from coastal seawater from the Antarctic. On the basis of 16S rRNA gene sequence similarity analyses, the strain was most closely related to the type strains of Hahella chejuensis (93.0\%) and Hahella ganghwensis (92.1\%) in the Gammaproteobacteria. Phylogenetic investigations using 16S rRNA gene sequences showed that this Antarctic marine isolate formed a robust monophyletic clade with the two Hahella species but constituted a distinct phyletic line in the clade. The DNA G $+\mathrm{C}$ content of strain IMCC $3113^{\top}$ was 56.4 mol\% and the major respiratory quinone was Q-9. Several phenotypic and physiological characteristics, including the temperature range and $\mathrm{NaCl}$ optimum for growth, several enzyme activities and the cellular fatty acid composition, served to differentiate the strain from the two Hahella species. Therefore strain IMCC $3113^{\top}$ represents a novel species of the genus Hahella, for which the name Hahella antarctica sp. nov. is proposed. The type strain is

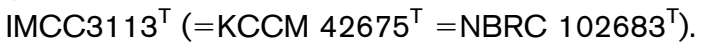

The genus Hahella (Lee et al., 2001) in the family Hahellaceae of the Gammaproteobacteria currently contains two species, Hahella chejuensis (Lee et al., 2001) and Hahella ganghwensis (Baik et al., 2005), which were isolated from marine sediments. $H$. chejuensis has been reported as a red-pigmented bacterial species, showing antibacterial and algicidal activities associated with the presence of antibiotic prodiginines (Jeong et al., 2005; Kim et al., 2007). H. ganghwensis is a cream-coloured, chemoheterotrophic bacterium that requires sea salts for growth (Baik et al., 2005). This study focuses on the taxonomic study of a non-pigmented bacterial strain, designated IMCC $3113^{\mathrm{T}}$, isolated from Antarctic coastal seawater. On the basis of its taxonomic properties, strain IMCC $3113^{\mathrm{T}}$ is considered to represent a novel species in the genus Hahella.

Strain IMCC $3113^{\mathrm{T}}$ was isolated from a seawater sample collected from the coast of King George Island, Weaver Peninsula, Antarctica ( $\left.62^{\circ} 14^{\prime} \mathrm{S} 58^{\circ} 47^{\prime} \mathrm{E}\right)$. Isolation of the strain was performed using the standard dilution-plating method on marine agar 2216 (MA; Difco) at $20{ }^{\circ} \mathrm{C}$ for 1 month. After the optimum growth temperature of the strain had been determined, cultures were maintained routinely on MA or marine broth 2216 (MB; Difco) at

The GenBank/EMBL/DDBJ accession number for the 16S rRNA gene sequence of strain IMCC $3113^{\top}$ is EF495227.

Transmission electron micrographs of cells of strain IMCC $3113^{\top}$ are available as a supplementary figure with the online version of this paper.
$25{ }^{\circ} \mathrm{C}$ and preserved as a glycerol suspension $(10 \%, \mathrm{v} / \mathrm{v})$ at $-75{ }^{\circ} \mathrm{C}$.

The methods used for DNA extraction, PCR and 16S rRNA gene sequencing have been described elsewhere (e.g. Cho \& Giovannoni, 2003). The resultant almost-complete 16S rRNA gene sequence (1485 bp) of strain IMCC $3113^{\mathrm{T}}$ was aligned with its nearest neighbours by using the ARB software package (Ludwig et al., 2004). The 16S rRNA gene sequence similarity between strain IMCC $3113^{\mathrm{T}}$ and other related species was calculated using the alignment based on the secondary structure of the $16 \mathrm{~S}$ rRNA with the ARB software. On the basis of $16 \mathrm{~S}$ rRNA gene sequence similarities, the strain was most closely related to $H$. chejuensis KCTC $2396^{\mathrm{T}}$ (93.0\%), H. ganghwensis KCTC $12277^{\mathrm{T}}(92.1 \%)$ and Oleiphilus messinensis DSM $13489^{\mathrm{T}}$ $(90.6 \%)$. No other bacterial species with validly published names exceeded $90 \%$ 16S rRNA gene sequence similarity. To clarify the phylogenetic position of the strain, 1294 unambiguously aligned nucleotide positions, determined from 16S rRNA gene sequences of 28 members of the Oceanospirillales, were used for phylogenetic analyses in PAUP $^{\star} 4.0$ beta 10 (Swofford, 2002). Phylogenetic trees were generated using neighbour joining (Saitou \& Nei, 1987) with Jukes-Cantor distance corrections (Jukes \& Cantor, 1969), maximum parsimony (Fitch, 1971) and maximum likelihood (Felsenstein, 1981). The robustness of the neighbour-joining and maximum-likelihood trees was confirmed by bootstrap analyses based on 1000 and 100 


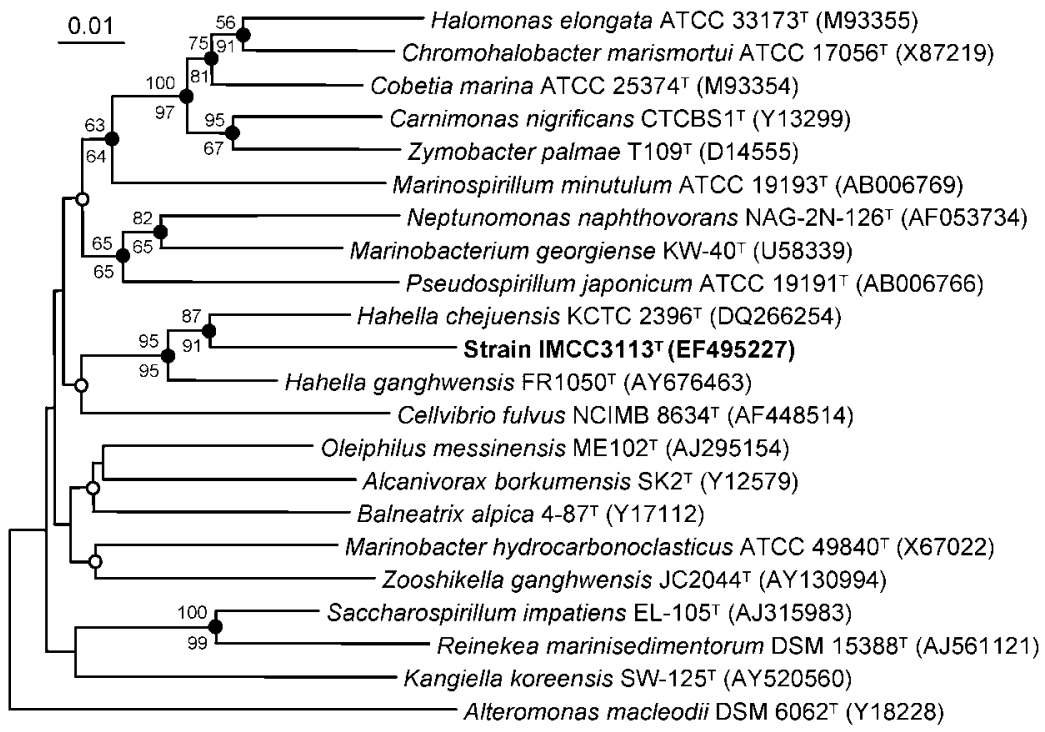

Fig. 1. Neighbour-joining phylogenetic tree, based on 16S rRNA gene sequences, showing the relationships between strain IMCC $3113^{\top}$ and representatives of the Gammaproteobacteria. Bootstrap percentages $(>50 \%)$ from both the neighbour-joining approach (above nodes) and the maximumparsimony approach (below nodes) are shown. Filled and open circles indicate nodes recovered reproducibly by all treeing methods or by two treeing methods, respectively. Bar, 0.01 substitutions per nucleotide position.

resamplings of the sequences, respectively. In all of the phylogenetic trees generated in this study (Fig. 1), strain $\mathrm{IMCC}_{11} 3^{\mathrm{T}}, H$. chejuensis KCTC $2396^{\mathrm{T}}$ and H. ganghwensis KCTC $12277^{\mathrm{T}}$ formed a monophyletic clade with strong bootstrap support. The branching-order patterns between the three strains in the clade were recovered consistently in all of the phylogenetic trees. This monophyletic clade was clustered with Cellvibrio fulvus NCIMB $8634^{\mathrm{T}}$ in the neighbour-joining and maximum-likelihood trees. However, this phylogenetic relationship was not supported by bootstrap analyses. This phylogenetic inference, coupled with 16S rRNA gene sequence similarities of

Table 1. Characteristics that differentiate strain IMCC $3113^{\top}$ from the type strains of the two Hahella species

Data for H. chejuensis KCTC $2396^{\mathrm{T}}$ and H. ganghwensis KCTC $12277^{\mathrm{T}}$ were taken from Lee et al. (2001) and Baik et al. (2005), respectively. All three strains are positive for catalase, alkaline phosphatase, esterase (C4), esterase lipase (C8), leucine arylamidase and acid phosphatase. All three strains are negative for indole production, arginine dihydrolase, urease, trypsin, $\alpha$-chymotrypsin, $\alpha$-galactosidase, $\beta$-galactosidase, $\beta$-glucuronidase, $N$ acetyl- $\beta$-glucosaminidase, $\alpha$-mannosidase and $\alpha$-fucosidase. + , Positive; - , negative; w, weakly positive.

\begin{tabular}{|c|c|c|c|}
\hline Characteristic & $\operatorname{IMCC}_{1113}{ }^{\mathrm{T}}$ & H. chejuensis KCTC $2396^{\mathrm{T}}$ & H. ganghwensis KCTC $12277^{\mathrm{T}}$ \\
\hline Isolation source & Antarctic seawater & Sea sediment & Tidal flat sediment \\
\hline Cell size (length $\times$ width, $\mu \mathrm{m}$ ) & $0.9-5.9 \times 0.4-0.8$ & $1.6-9.0 \times 0.5-0.7$ & $1.0-1.5 \times 0.4-0.5$ \\
\hline Pigmentation & Cream & Red & Cream \\
\hline Motility & - & + & + \\
\hline Temperature range for growth $\left({ }^{\circ} \mathrm{C}\right)$ & $3-25$ & $10-45$ & $15-40$ \\
\hline Optimum $\mathrm{NaCl}$ concentration (\%) for growth & 2 & 2 & $4-6$ \\
\hline Anaerobic growth & $\mathrm{W}$ & $-*$ & - \\
\hline Nitrate reduction & + & + & - \\
\hline Acid production from glucose & - & + & - \\
\hline \multicolumn{4}{|l|}{ Hydrolysis of: } \\
\hline Aesculin & - & + & + \\
\hline Gelatin & - & + & + \\
\hline \multicolumn{4}{|l|}{ Enzyme activity } \\
\hline Oxidase & - & + & + \\
\hline Lipase (C14) & - & $\mathrm{W}$ & + \\
\hline Valine arylamidase & - & + & $\mathrm{w}$ \\
\hline Cystine arylamidase & - & $\mathrm{W}$ & - \\
\hline Naphthol-AS-BI-phosphohydrolase & - & + & + \\
\hline$\alpha$-Glucosidase & + & - & + \\
\hline DNA G $+\mathrm{C}$ content $(\mathrm{mol} \%)$ & 56.4 & 55 & 44 \\
\hline
\end{tabular}

${ }^{\star}$ Data from Baik et al. (2005). 
$<97 \%$ (Wayne et al., 1987) between strain IMCC3113 and the two Hahella species, suggested that the strain should be assigned to the genus Hahella as a representative of a novel species.

Phenotypic and physiological characterization was carried out according to a previous study (Choo et al., 2007) and standard methods (Smibert \& Krieg, 1994), using MA as the basal medium at $25{ }^{\circ} \mathrm{C}$, unless otherwise specified. The cell morphology was examined using liquid cultures grown aerobically in MB for 2 days. The colony morphology was observed using colonies grown on MA for 5 days. Flagellar motility was investigated using wet mounts prepared from fresh cultures grown in $\mathrm{MB}$ at $25{ }^{\circ} \mathrm{C}$ for 2 days. The growth temperature range and optimum were tested from 3 to $42{ }^{\circ} \mathrm{C}$. The $\mathrm{pH}$ range and optimum for growth were examined on MA adjusted to $\mathrm{pH}$ values from 4.0 to 12.0. The $\mathrm{NaCl}$ concentrations and optimum for growth were determined in $\mathrm{NaCl}$-free artificial seawater medium (Choo et al., 2007) supplemented with $5.0 \mathrm{~g}$ peptone, $1.0 \mathrm{~g}$ yeast extract and various concentrations of $\mathrm{NaCl}(0-15 \%, w / v)$. Biochemical tests and carbon-source oxidation tests were carried out using API 20NE and API ZYM strips (bioMérieux) and in GN2 microplates (Biolog), according to the manufacturers' instructions, using inoculation with bacterial suspensions in artificial seawater medium. Ten different antimicrobial agents (listed in the species description) were tested using the diffusion plate method (Jorgensen et al., 1999). The DNA G $+\mathrm{C}$ content was determined using HPLC (Mesbah et al., 1989). Cellular fatty acid methyl esters were prepared from cultures grown on MA at $25{ }^{\circ} \mathrm{C}$ for 4 days and then analysed, according to the MIDI Microbial Identification System, by the Korean Culture Center of Microorganisms (Seoul, Republic of Korea). Respiratory quinones were analysed, using reversed-phase HPLC, by the Korean Culture Center of Microorganisms (Komagata \& Suzuki, 1987).

The phenotypic and biochemical characteristics determined for strain IMCC $3113^{\mathrm{T}}$ are given in Table 1 and the species description. The DNA G $+\mathrm{C}$ content of the strain was $56.4 \mathrm{~mol} \%$ and the major cellular fatty acid constituents are given in Table 2. Overall, cells of strain IMCC $3113^{\mathrm{T}}$ were Gram-negative, psychrotolerant, aerobic, chemoheterotrophic, non-motile, granule-containing and irregularly rod-shaped. Transmission electron micrographs of the cells are shown in Supplementary Fig. S1 (available in IJSEM Online). The phylogenetic analyses in this study showed that strain IMCC $3113^{\mathrm{T}}$ belonged to the genus Hahella. However, strain IMCC $3113^{\mathrm{T}}$ and the two Hahella species could be differentiated from each other on the basis of the levels of 16S rRNA gene sequence similarity (92.1$93.0 \%$ ) and several phenotypic properties, including cell size, the temperature range for growth, oxidase activity, nitrate reduction, several enzyme activities and the proportions of major fatty acids, as shown in Tables 1 and 2. Therefore strain IMCC $3113^{\mathrm{T}}$ represents a novel species of the genus Hahella, for which the name Hahella antarctica sp. nov. is proposed.

\section{Description of Hahella antarctica sp. nov.}

Hahella antarctica (an.tarc'ti.ca. N.L. fem. adj. antarctica of the Antarctic, where the type strain was isolated).

Gram-negative, non-motile, aerobic, psychrotolerant and chemoheterotrophic. Cells are straight or irregular rods, $0.9-5.9 \mu \mathrm{m}$ long and $0.4-0.8 \mu \mathrm{m}$ wide. Colonies grown on $\mathrm{MA}$ at $25{ }^{\circ} \mathrm{C}$ for 5 days are $0.5-1.0 \mathrm{~mm}$ in diameter, circular, pulvinate with entire margins, dry, hard and cream-coloured. Growth occurs at $3-25{ }^{\circ} \mathrm{C}$ (optimum, $25{ }^{\circ} \mathrm{C}$ ), pH 5-10 (optimum, pH 7) and with 0.5-5.0\% $\mathrm{NaCl}$ (optimum, 2.0\%). Other phenotypic and physiological characteristics are given in Table 1. Oxidizes the following carbon substrates (Biolog GN2 microplates): melibiose, acetic acid, cis-aconitic acid, citric acid, Dgalacturonic acid, D-gluconic acid, D-glucuronic acid, $\beta$ hydroxybutyric acid, propionic acid, bromosuccinic acid, glucuronamide, L-aspartic acid, L-histidine, hydroxy-Lproline, L-leucine, L-serine and inosine. Does not oxidize the following carbon substrates: $\alpha$-cyclodextrin, dextrin, Tween 40, Tween $80, \alpha$-D-glucose, maltose, $N$-acetyl-Dgalactosamine, $\mathrm{N}$-acetyl-D-glucosamine, adonitol, L-arabinose, D-arabitol, cellobiose, i-erythritol, D-fructose, Lfucose, D-galactose, gentiobiose, myo-inositol, $\alpha$-D-lactose, lactulose, D-mannitol, D-mannose, methyl $\beta$-D-glucoside, Dpsicose, raffinose, L-rhamnose, D-sorbitol, sucrose, trehalose, turanose, xylitol, pyruvic acid methyl ester, succinic acid monomethyl ester, $\alpha$-ketobutyric acid, $\alpha$-ketovaleric acid, formic acid, D-galactonic acid lactone, D-glucosaminic acid, $\alpha$-hydroxybutyric acid, $\gamma$-hydroxybutyric acid,

Table 2. Cellular fatty acid compositions (\%) of strain IMCC $3113^{\top}$ and the type strains of the two Hahella species

Data for reference strains were taken from Baik et al. (2005). Only fatty acids amounting to at least $1 \%$ of the total cellular fatty acid content of one or more of the strains are shown. All species were grown on MA. -, Not detected.

\begin{tabular}{|c|c|c|c|}
\hline Fatty acid & IMCC $3113^{\mathrm{T}}$ & $\begin{array}{l}\text { H. chejuensis } \\
\text { KCTC } 2396^{\mathrm{T}}\end{array}$ & $\begin{array}{c}H . \\
\text { ganghwensis } \\
{\text { KCTC } 12277^{\mathrm{T}}}^{\mathrm{T}}\end{array}$ \\
\hline $\mathrm{C}_{10: 0}$ & 2.8 & - & - \\
\hline $\mathrm{C}_{12: 0}$ & 3.2 & 1.3 & 2.4 \\
\hline $\mathrm{C}_{12: 0} 3-\mathrm{OH}$ & 7.1 & 2.5 & 3.8 \\
\hline $\mathrm{C}_{14: 0}$ & 1.3 & 2.8 & 2.4 \\
\hline $\mathrm{C}_{16: 0}$ & 22.5 & 12.5 & 18.1 \\
\hline $\mathrm{C}_{16: 0} \mathrm{~N}$ alcohol & 1.5 & 6.5 & 7.2 \\
\hline $\mathrm{C}_{16: 1} \omega 9 c$ & 0.7 & 3.2 & 8.8 \\
\hline$C_{17: 0}$ 10-methyl & 3.8 & 14.4 & - \\
\hline $\mathrm{C}_{17: 1} \omega 8 c$ & 0.2 & - & 1.4 \\
\hline $\mathrm{C}_{18: 0}$ & 0.9 & 2.8 & 1.1 \\
\hline $\mathrm{C}_{18: 1} \omega 7 c$ & 10.4 & 9.4 & $<1$ \\
\hline $\mathrm{C}_{18: 1} \omega 9 c$ & 8.2 & 19.8 & 39.0 \\
\hline $\mathrm{C}_{18: 3} \omega 6 c$ & 3.6 & 10.7 & 9.0 \\
\hline Summed feature $3^{\star}$ & 31.6 & 11.9 & 3.3 \\
\hline
\end{tabular}

${ }^{*}$ Comprises $\mathrm{C}_{16: 1} \omega 7 c$ and/or iso- $\mathrm{C}_{15: 0} 2-\mathrm{OH}$. 
$p$-hydroxyphenylacetic acid, $\alpha$-ketoglutaric acid, DL-lactic acid, malonic acid, quinic acid, D-saccharic acid, sebacic acid, succinic acid, succinamic acid, L-ornithine, L-phenylalanine, L-pyroglutamic acid, D-serine, DL-carnitine, $\gamma$-aminobutyric acid, urocanic acid, uridine, thymidine, phenylethylamine, putrescine, 2-aminoethanol, 2,3-butanediol, glycerol, DL- $\alpha$ glycerol phosphate, $\alpha$-D-glucose 1-phosphate, D-glucose 6phosphate, L-alaninamide, D- and L-alanine, L-alanyl glycine, L-asparagine, L-glutamic acid, glycyl L-aspartic acid, glycyl Lglutamic acid, L-proline and L-threonine. Susceptible to gentamicin $(10 \mu \mathrm{g})$, kanamycin $(30 \mu \mathrm{g})$, penicillin $\mathrm{G}(10 \mu \mathrm{g})$, rifampicin $(50 \mu \mathrm{g})$, streptomycin $(10 \mu \mathrm{g})$ and tetracycline $(30 \mu \mathrm{g})$, but resistant to ampicillin $(10 \mu \mathrm{g})$, chloramphenicol $(25 \mu \mathrm{g})$, erythromycin $(15 \mu \mathrm{g})$ and vancomycin $(30 \mu \mathrm{g})$. Cellular fatty acid profile is given in Table 2. Major respiratory quinone is Q-9. DNA G+C content is $56.4 \mathrm{~mol} \%$.

The type strain, $\mathrm{IMCC} 3113^{\mathrm{T}}\left(=\mathrm{KCCM} 42675^{\mathrm{T}}=\mathrm{NBRC}\right.$ $102683^{\mathrm{T}}$ ), was isolated from a surface seawater sample from Maxwell Bay, King George Island, western Antarctica.

\section{Acknowledgements}

We are grateful to Dr Soon-Gyu Hong and Dr Il-Chan Kim for providing Antarctic seawater samples. This research was supported by a research grant (PE07050) from the Korea Polar Research Institute.

\section{References}

Baik, K. S., Seong, C. N., Kim, E. M., Yi, H., Bae, K. S. \& Chun, J. (2005). Hahella ganghwensis sp. nov., isolated from tidal flat sediment. Int J Syst Evol Microbiol 55, 681-684.

Cho, J.-C. \& Giovannoni, S. J. (2003). Parvularcula bermudensis gen. nov., sp. nov., a marine bacterium that forms a deep branch in the $\alpha$ Proteobacteria. Int J Syst Evol Microbiol 53, 1031-1036.

Choo, Y.-J., Lee, K., Song, J. \& Cho, J.-C. (2007). Puniceicoccus vermicola gen. nov., sp. nov., a novel marine bacterium, and description of Puniceicoccaceae fam. nov., Puniceicoccales ord. nov., Opitutaceae fam. nov., Opitutales ord. nov. and Opitutae classis nov. in the phylum 'Verrucomicrobia'. Int J Syst Evol Microbiol 57, 532-537.

Felsenstein, J. (1981). Evolutionary trees from DNA sequences: a maximum likelihood approach. J Mol Evol 17, 368-376.
Fitch, W. M. (1971). Toward defining the course of evolution: minimum change for a specific tree topology. Syst Zool 20, 406-416.

Jeong, H., Yim, J. H., Lee, C., Choi, S. H., Park, Y. K., Yoon, S. H., Hur, C. G., Kang, H. Y., Kim, D. \& other authors (2005). Genomic blueprint of Hahella chejuensis, a marine microbe producing an algicidal agent. Nucleic Acids Res 33, 7066-7073.

Jorgensen, J. H., Turnidge, J. D. \& Washington, J. A. (1999). Antibacterial susceptibility tests: dilution and disk diffusion methods. In Manual of Clinical Microbiology, pp. 1526-1543. Edited by P. R. Murray, E. J. Baron, M. A. Pfaller, F. C. Tenover \& R. H. Yolken. Washington, DC: American Society for Microbiology.

Jukes, T. H. \& Cantor, C. R. (1969). Evolution of protein molecules. In Mammalian Protein Metabolism, vol. 3, pp. 21-132. Edited by H. N. Munro. New York: Academic Press.

Kim, D., Lee, J. S., Park, Y. K., Kim, J. F., Jeong, H., Oh, T. K., Kim, B. S. \& Lee, C. H. (2007). Biosynthesis of antibiotic prodiginines in the marine bacterium Hahella chejuensis KCTC 2396. J Appl Microbiol 102, 937-944.

Komagata, K. \& Suzuki, K. (1987). Lipid and cell-wall analysis in bacterial systematics. Methods Microbiol 19, 161-203.

Lee, H. K., Chun, J., Moon, E. Y., Ko, S. H., Lee, D. S., Lee, H. S. \& Bae, K. S. (2001). Hahella chejuensis gen. nov., sp. nov., an extracellularpolysaccharide-producing marine bacterium. Int J Syst Evol Microbiol 51, 661-666.

Ludwig, W., Strunk, O., Westram, R., Richter, L., Meier, H., Yadhukumar, Buchner, A., Lai, T., Steppi, S. \& other authors (2004). ARB: a software environment for sequence data. Nucleic Acids Res 32, 1363-1371.

Mesbah, M., Premachandran, U. \& Whitman, W. B. (1989). Precise measurement of the $\mathrm{G}+\mathrm{C}$ content of deoxyribonucleic acid by highperformance liquid chromatography. Int J Syst Bacteriol 39, 159-167.

Saitou, N. \& Nei, M. (1987). The neighbor-joining method: a new method for reconstructing phylogenetic trees. Mol Biol Evol 4, 406-425.

Smibert, R. M. \& Krieg, N. R. (1994). Phenotypic characterization. In Methods for General and Molecular Bacteriology, pp. 607-654. Edited by P. Gerhardt, R. G. E. Murray, W. A. Wood \& N. R. Krieg. Washington, DC: American Society for Microbiology

Swofford, D. (2002). PAUP*: Phylogenetic analysis using parsimony (and other methods), version 4. Sunderland, MA: Sinauer Associates.

Wayne, L. G., Brenner, D. J., Colwell, R. R., Grimont, P. A. D., Kandler, O., Krichevsky, M. I., Moore, L. H., Moore, W. E. C., Murray, R. G. E. \& other authors (1987). International Committee on Systematic Bacteriology. Report of the ad hoc committee on reconciliation of approaches to bacterial systematics. Int J Syst Bacteriol 37, 463-464. 